\title{
Factors Affecting Customer Citizenship Behavior: A Model of University Students
}

\author{
El Sayed A. Nagy ${ }^{1} \&$ Wafaa Galal Marzouk ${ }^{2}$ \\ ${ }^{1}$ Faculty of Management Sciences, MSA University, Egypt \\ ${ }^{2}$ Faculty of Commerce, Cairo University, Egypt \\ Correspondence: El Sayed A. Nagy, Faculty of Management Sciences, MSA University, Egypt.
}

Received: December 12, 2017

Accepted: January 5, 2018 Online Published: February 3, 2018

doi:10.5539/ijms.v10n1p54

URL: https://doi.org/10.5539/ijms.v10n1p54

\begin{abstract}
The purpose of this research is to measure the dimensions of student citizenship behavior and the extent of student satisfaction, loyalty, commitment, and trust as integrated factors are antecedents of student citizenship behavior in universities. A sample of 400 students in two private universities in Egypt was selected randomly and a structured questionnaire was used to collect the research data. The student citizenship behavior was found to contain two types of voluntary behavior; voluntary cooperative behavior and voluntary participation behavior. Also, despite the strong and significant interrelationships between the four antecedents of student citizenship behavior, student satisfaction and loyalty can be considered the strongest antecedents of all dimensions of student citizenship behavior in universities. The main implication of this research is that universities should consider students as valuable resources in both their formal roles and voluntary behavior that support the educational environment of a university. The research suggests satisfied and loyal students provide advantages to their universities not only through spreading positive word of mouth about their universities, attending further education in the future and supporting their universities in the community but also through their positive voluntary behavior.
\end{abstract}

Keywords: student citizenship behavior, student satisfaction, loyalty, commitment, trust

\section{Introduction}

In a highly competitive and changing business environment of today, much consideration has been paid for the behavior of the citizen, the customer in the marketing and management literature. Like the organization's employees, customers may commit to a variety of conducted behavior of the citizen in a particular organization, especially in service-based organizations (Abbas et al., 2011; Abolfathi et al., 2013). Customers act as productive resources by creating suggestions for service development, purchasing other services, giving suggestions to others, attending brand-centered events, and participating in brand communities (Ercsey, 2016; Johnson \& Rapp, 2010; Jung \& Yoo, 2017). A sequence of studies perceives this positive role of customer behavior and proposes the concept of customer citizenship behavior and voluntary performance (Bettencourt, 1997; Groth, 2005).

Groth (2005) primarily developed the customer citizenship behavior concept (CCB) as "voluntary and discretionary behaviors that are not required for the successful production and/or delivery of the service but that, in the aggregate, help the service organization overall" (Groth, 2005, p. 11). Prior researchers have suggested that this behavior positively influence the performance of the parties involved in the service environment; the service employees, the organization, and even other customers, and can create an attractive business environment for all those parties (Lara, 2015; Yang \& Qinhai, 2011). As indicated by Dai et al. (2014) and Ponnusamy \& Ho (2015), citizen customers will enhance the organizational performance and its effectiveness through such behavior as, continuous purchasing, providing suggestions for organizational improvements, suggesting the organization to others, as well as attracting new customers and therefore these advantages can make a potential source of competitive advantage for that business without any cost. Abolfathi et al. (2013) and Yi et al. (2013) demonstrated that CCB may prompt a favorable service environment and superior quality in light of the fact that customer displaying citizenship behavior may stimulate other customers to do the same, beginning a chain of voluntary activities. Recently, Tsai et al. (2017) proposed that when an individual involves in a service delivery, the interactions between this person and others (e.g., service employees and other customers) transform to 
his/her personal experiences, which then develop his/her capability to perform customer citizenship behavior.

Considering the significance of voluntary behavior of customers in firm's performance, most of the previous studies were concerned with customer citizenship of services organizations and few of them have discussed this concept from the students' perspective as customers who may have kinds of voluntary behavior in their universities. Accordingly, the main objective of this research is to explore customer citizenship behavior in universities through examining the related factors that shape their citizenship behavior. The following sections focus on the literature review of previous studies on customer citizenship behavior, the research hypotheses, the research methodology, the fundamental results and discussions of the findings, and the research implications and suggestions, respectively.

\section{Literature Review}

Customer citizenship behavior has become a popular topic in marketing as a result of its implications for service performance. Previous studies related to this concept may be divided into three groups of studies: (1) studies focus on the customer citizenship behavior to develop measurements for this concept, (2) studies determine main antecedents of this behavior such as customer satisfaction, customer commitment, corporate reputation, customer trust, customer justice perception and customer perceived service quality in different types of organizations, and (3) studies consider the impact of citizenship behavior on employee performance, customer turnover intention, and service quality. These kinds of studies are out of the scope of the present research.

\subsection{Studies of Customer Citizenship Behavior (CCB) Dimensions}

The service marketing literature described several scales of customer citizenship behavior. These scales have distinctive measurements ranging from three to eight dimensions. The straightforward construct incorporates merely three measurements; the most sophisticated construct combines twenty-nine measurements. Some studies recognized this concept as a one-dimensional construct; while other studies have viewed it as a multidimensional construct. Others proposed the concept as formative construct adjusted from organization citizenship behavior scale.

Bettencourt (1997) proposed three measurements of customer citizenship behavior: loyalty, cooperation, and participation corresponding to three important customer roles considered by service scholars as a promoter, a human resource, and an organizational consultant for the firm. Groth (2005) developed and provided preliminary evidence with the convergent and discriminant validity of the measure that is utilized in subsequent researches. The scale proposed three diverse citizenship behavior in internet services which are recommending the services to others, providing help and assistance to customers, and giving feedback and ideas to the organization. In the line of Groth's (2005) scale of CCB, recent studies have provided empirical evidence that customer citizenship behavior is multidimensional construct including similar measurements suggested by Groth's (2005) (Aggarwal \& Soch, 2013; Bartikwoski \& Walsh,2011; Soch \& Aggarwal, 2013).

Bove et al. (2009) expanded the voluntary actions to eight measurements derived from the organizational behavior and marketing and are applicable across several contexts. (1) Communicating positive word of mouth among customers. (2) Communication of customers to others. (3) Participating in organizational events. (4) Getting involved in charitable actions with the organization. (5) Adapting to organizational situations beyond their control. (6) Suggesting of ideas for organizational improvement. (7) Directing the complaint to the organization. (8) Observing other customers to appropriate behavior. Johnson \& Rapp (2010) proposed and validated two distinguished multidimensional scales of $\mathrm{CCB}$ for for-profit organizations and another for nonprofit organizations. In a theoretical study, Yu-hong et al. (2013) categorized customer citizenship behavior into $\mathrm{CCBO}$ (customer citizenship behavior for the organization) and CCBI (customer citizenship behavior for individuals). CCBO provides benefits to the community directly, for example, saying positive words of the community to others or giving constructive suggestions for the improvement of the community. CCBI is directed towards other consumers in the community, directly beneficial to the individual consumers and indirectly beneficial to the community, such as posting to share information, knowledge and consumption experiences with others or making responses to the helping request from other members.

In summary, according to the measurements of customer citizenship behavior revealed from previous studies, the concept mainly encompasses voluntary and helping behavior. Specifically, this behavior takes diverse forms such as feedback behavior that addresses valuable information and suggestions of customers to enhance the organization and its processes, recommendation organization or its employees through positive word of mouth (cooperation), and helping behavior to assist other customers as well as employees during the service process (participation). Therefore, the first hypothesis of this research is: 
$\mathrm{H}_{1}$ : Student citizenship behavior in universities can be categorized into two voluntary behaviors, cooperation, and participation behaviors.

\subsection{Studies of the Interrelationships among Customer Satisfaction, Trust, Commitment and Loyalty}

Service marketing studies have examined the interrelationships among the constructs of satisfaction, loyalty, commitment, and trust. For instance, Ponnusamy \& Ho (2015) proved that when customers are satisfied by their online retailers, they tend to stay loyal through continuous shopping, spreading positive word-of-mouth to their friends/relatives, and willingness to purchase from that retailer in the future. Picon et al. (2014) recommended that the positive assessment of the product or service that the customer acquires is a major noteworthy to pursue a relationship with a company's products or services, and a critical support that maintains loyalty. Moreover, Noyan \& Simsek (2014) concluded that customer satisfaction is the most vital predictor of customer loyalty than comparative product prices, product discounts, and gifts, product and service quality, values of supermarkets chains in Turkey. In higher education services, Tomas (2011) suggested that satisfied students are positively affecting the educational quality system through effective participation and a loyalty behavior in leading universities in India.

From another perspective, Balaji (2015) and Hennig-Thurau et al. (2001) supported the positive relationship between customer satisfaction and commitment. In their recent studies, Chen et al. (2015) and Schirmer et al. (2016) concluded that highly customers' satisfaction foster customers to develop emotional link and continuous commitment to their organizations. Moreover, Chiu et al. (2015) concluded that the cumulative assessment of customers to their satisfactory experiences positively influence their committed relationships with their organizations in the future. Furthermore, previous studies empirically confirmed the linkage between trust and satisfaction. For instance, Kaur \& Soch (2013) revealed satisfaction as a strong factor affecting customer trust. In the educational field, Rojas-Mendez et al. (2009) supported that students' trust is described as the degree of student's confidence in their universities integrity and dependability as well as it is enhanced through students' experiences with their staff.

Empirical research in the services context supports the notion that commitment influences loyalty directly. Henning-Thurau et al. (2001) found that students' emotional commitment is one of the essential factors of their loyalty. As indicated by Balaji (2015) and Schirmer et al. (2016), commitment and loyalty are closely related but distinct constructs. Commitment captures the relationship strength or stickiness, whereas loyalty reflects the attitudes and behavior that commitment evokes. Other empirical studies tested the relationship between customer loyalty and trust. For example, El-Manstrly et al. (2011) and Roostika (2011) revealed that the relative effect of trust on loyalty is stronger than the effect of other factors such as switching cost or service quality. Furthermore, based on the commitment-trust theory of relationship marketing, trust and commitment are the main determinants of relationship marketing (Morgan \& Hunt, 1994). Aurier \& Goala (2010) showed that when customers have confidence in their organizations to meet their expectations in the short and long term, they are willing to commit themselves to that organization.

In summary, it can be seen that most previous researches investigated the relationship between two variables (antecedents of customer citizenship behavior) but the interrelationship between all of these antecedents were not studies. Therefore, the second hypothesis of this study is $\mathrm{H}_{2}$ : Significant interrelationships exist between all antecedents of student citizenship behavior.

\subsection{Studies of Factors/Antecedents Affecting Customer Citizenship Behavior}

Most of the previous studies identified four groups of antecedents affecting the customer citizenship behavior, customer satisfaction, loyalty, commitment, and trust. A few of them investigated other factors such as organizational justice and corporate reputation but they found weak and/or indirect impact of these factors on customer citizenship behavior. Therefore, this research concentrates on the four factors as integrated factors representing antecedents affect customer citizenship behavior.

\subsubsection{Customer Satisfaction and Customer Citizenship Behavior}

The influence of customer satisfaction on customer citizenship behavior has been examined by many studies, but the results are still not consistent. For example, Groth (2005) empirically provided support for customers that would engage in a citizenship behavior as a return to the organization when they received treatment exceeding their expectations. Lara's (2015) study supported the findings of Groth (2005) and showed the mediating role of satisfaction with hotel service in the relationship between fair treatment of the staff and customer citizenship behavior. In consumption virtual communities, Chen et al. (2015) and Ponnusamy \& Ho (2015) found that e-satisfaction significantly influences all measurements of e-customer citizenship behavior. Lee et al. (2014) 
suggested that customer satisfaction has a significant impact on customer loyalty, cooperation, and participation as dimensions of customer citizenship behavior.

\subsubsection{Customer Loyalty and Customer Citizenship Behavior}

Some studies found that loyal customers hold more experience than the nonloyal customers that may empower them to provide more voluntary actions to their organizations (Flint et al., 2011; Wirtz \& Mattila, 2003). Abbas et al. (2011) and Macintosh (2002) showed that loyalty of customers has a significant and positive relationship with citizenship dimensions of helping other customers and the organization. Recenlty, Ponnusamy \& Ho (2015) concluded that the customer loyalty is the main predictor of customer citizenship behavior in online shopping. However, another stream of studies suggested different empirical results. Bartikowski \& Walsh (2011) showed that customer's loyalty influences only the helping citizenship behavior to the organization, but it does not have any impact on helping citizenship behavior to other customers. Anaza \& Zhao's results (2013) were opposite to Bartikowski \& Walsh's (2011) findings that loyalty significantly impacts customer citizenship behavior that helps the organization as well as other customers in online purchase setting. Abbasi \& Zivarmoghbeli (2014) could not prove the relationship between customer loyalty and customer citizenship behavior in Iranian banks.

\subsubsection{Customer Commitment and Customer Citizenship Behavior}

Various researchers provided theoretical and empirical evidence for the extent of customer commitment shape customer citizenship behavior. Bove et al. (2009) empirically proved that commitment to the service staff is the strongest predictor of customer citizenship behavior. Further, Curth et al. (2014) suggested that commitment to fellow customers and commitment to the service organization is directly linked to customer-directed citizenship behavior (helping behavior) and indirectly influence organization-directed CCB (positive and negative feedback, monitoring behavior) through a commitment to the service provider. Mosavi \& Ghaedi (2012) found that highly committed customers were more interested to dispread positive word-of-mouth, share useful information with other customers, and provide support in organization's marketing research. Dai et al. (2014) confirmed that customer commitment plays a more important role than customer satisfaction and trust in predicting customers' willingness for displaying overall customer citizenship behavior. Recently, Tan et al. (2017) asserted that committed students perform voluntary actions because they believe in university's goals, values, and its welfare. However, other few studies (e.g., Anaza \& Zhao, 2013; Chen et al., 2015) could not prove the positive relationship between commitment and customer citizenship behavior. Bettencourt (1997) only found support for the significant relationship between customer commitment and loyalty and participation citizenship behavior.

\subsubsection{Customer Trust and Customer Citizenship Behavior}

Several studies have supported the positive link between customer trust and customer citizenship behavior. Empirical results of Wingwon \& Piriyakul (2010) showed that trust has a direct and positive influence on customer citizenship behavior. In line with this, Yu-hong et al. (2013) developed a theoretical model containing community trust as an important antecedent of CCB in a consumption virtual community. They proposed that customers will trust the community when they perceive the honesty and benevolence of the community, and this kind of trust will encourage members to engage in beneficial behavior to the community. Abbasi \& Zivarmoghbeli (2014) found that customer trust has the most effect on customer citizenship behavior than satisfaction, reputation, and commitment variables. The study of Di et al. (2010) revealed that when customers perceive that retailers are worth trusting, they will have citizenship behavior above their purchase requirements behavior such as voluntary helping retailers in certain operations and doing promotion for those retailers to their friends. However, Mosavi \& Ghaedi (2012) found that trust indirectly influences customer citizenship behavior through commitment. Dai et al. (2014) found that trust marginally emerges as a significant predictor of only two dimensions of customer citizenship behavior, the extent to which customers exhibit loyalty and cooperative behavior. In accordance the third hypothesis of this study is:

$\mathrm{H}_{3}$ : Student satisfaction, loyalty, commitment, and trust as antecedents are integrated and significantly affect the student citizenship behavior.

\section{The Research Problem}

Most of the literature, as previously indicated, has primarily focused on the antecedents $\mathrm{CCB}$, in addition to $\mathrm{CCB}$ measurements. However, there are gaps in the literature regarding the measurements of this concept and the factors constituting it. Firstly, customer citizenship behavior has received only a little attention in universities, which has certain characteristics. While this concept has been studied in numerous organizations such as retailing (Anaza \& Zhao, 2013; Aggarwal, 2013; Aggarwal \& Soch, 2013; Bartikowski \& Walsh, 2011; Bettencourt, 1997; Ponnusamy \& Ho, 2015; Soch \& Aggarwal, 2013), banking industry (e.g., Abbas et al., 2011; 
Abbasi \& Zivarmoghbeli, 2014; Abolfathi et al., 2013), hospitality services (eg., Dai et al., 2014; Lee et al., 2014), and internet service deliveries (e.g., Chen et al., 2015; Groth, 2005). Only research exists regarding this behavior in education, particularly from a staff perspective and the amplification of organizational citizenship behavior in universities. Therefore, examining the concept of citizenship behavior and its dimensions from student perspective in universities is likely to enhance the understanding of this behavior in different environmental settings. Secondly, although several factors are covered in the context of the predictors of customer citizenship behavior, most of the literature obviously addresses the interrelationships between a few of them only. Therefore, it is useful in this research to test the importance and interrelationships among these constructs together without testing the causal ordering of them. Thirdly, to date, a variety of the antecedents of customer citizenship behavior have been suggested, however, still, the results are not consistent and could not fully support the positive relationship between these factors and customer citizenship behavior. Fourthly, combining all possible antecedents has not received much attention in the research; most of the previous studies measured the link between one or two factors and the customer citizenship behavior. Therefore, more interrelationships among antecedents may be useful to test how the combined factors can determine customer citizenship behavior particularly; these factors are interrelated according to previous research findings. The research problem may be identified in these questions:

1) What are the main dimensions of student citizenship behavior in universities?

2) Are the antecedents of student satisfaction, loyalty, commitment, and trust in universities interrelated?

3) To what extent the student satisfaction, loyalty, commitment, and trust contribute to the student citizenship behavior in universities?

\section{The Research Methodology}

\subsection{The research Model}

Based on the previously indicated hypotheses, a research model was developed, as indicated in Figure 1. Student citizenship behavior is the dependent variable and student satisfaction, loyalty, commitment, and trust are independent variables.

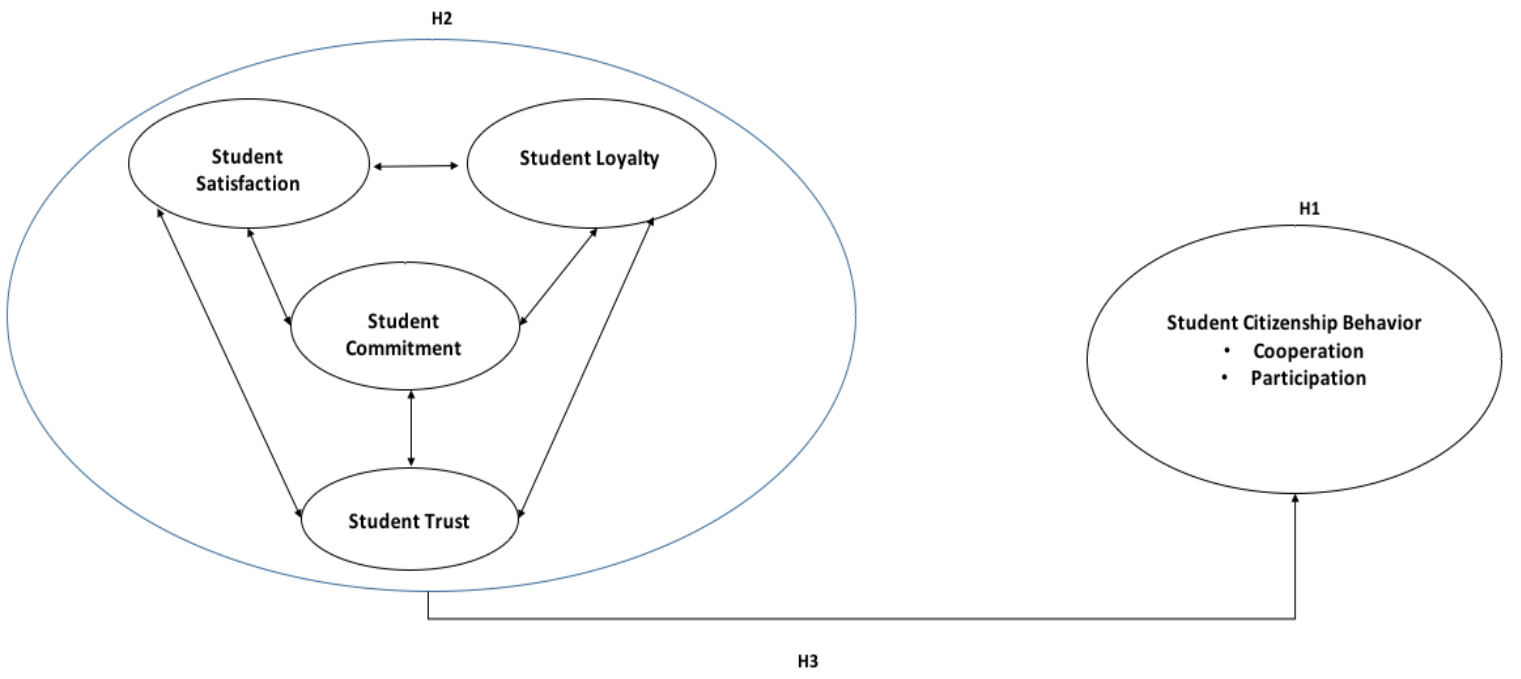

Figure 1. The research model

\subsection{The Research Variables and Measurements}

Table 1 presents the research variables and their measurements. The student citizenship behavior is conceptualized by the discretionary actions of students in their relations with staff/administrative and other students, and the students' active involvement in a university's governance and development. Student satisfaction measure relates to academic staff, administration staff, university infrastructures, support services and career opportunities. Student loyalty measure relates to attitudinal and behavioral items developed and validated by most loyalty researchers. Student commitment contains two dimensions: a continuous commitment in which students take certain actions to develop and maintain a continuous relationship with their universities and affective commitment, which is an emotional perception for a continuous relationship with universities. 
Student trust is multidimensional includes competence, integrity, dependability/reliability, and openness and honesty (Ghosh et al., 2016; Seppanen \& Blomqvist, 2007).

Table 1. The research variables and measurements

\begin{tabular}{|c|c|}
\hline Variables & Measurements \\
\hline Student citizenship behavi & $\begin{array}{l}\text { ISCB) (Bettencourt, 1997; Groth, 2005; Kotze \& Plessis, 2003) } \\
\text {-I completely follow my university procedures (SCB1). } \\
\text {-I fully cooperate with my university staff (SCB2). } \\
\text {-I assist other students to use my university's service correctly (SCB3). } \\
\text {-I am willing to wait longer to obtain a service from my university (SCB4). } \\
\text {-I usually protect my university facilities/equipment (SCB5). } \\
\text {-I help other students in my university when they need (SCB6). } \\
\text {-I generally participate with the staff of my university to facilitate their jobs (SCB7). } \\
\text {-I share my opinion with university staff (SCB8). } \\
\text {-I participate in events that support my university (SCB9). } \\
\text {-I provide information to my university even if I am not asked to do this (SCB10). }\end{array}$ \\
\hline $\begin{array}{l}\text { Student satisfaction(SAT) } \\
\text { Quality of academics }\end{array}$ & $\begin{array}{l}\text { Icli \& Anil, 2014; Helgesen \& Nesset, 2007; Tomas, 2011) } \\
\text {-I am satisfied with the qualified academic staff of my university (SAT1). } \\
\text {-My university provides me with the academic support I need (SAT2). } \\
\text { - I have good opportunities to communicate with academic staff in my university (SAT3). }\end{array}$ \\
\hline $\begin{array}{l}\text { Quality } \\
\text { administration }\end{array}$ & - The administrative staff of my university responds to my inquiries (SAT4). \\
\hline $\begin{array}{l}\text { Quality of providing } \\
\text { career opportunities }\end{array}$ & $\begin{array}{l}\text {-The educational program of my university ensures what I need for development (SAT5). } \\
\text {-The educational programs of my university support me in the job/market (SAT6). } \\
\text {-I am satisfied with the fair evaluation of my academic performance (SAT7). } \\
\text {-The educational system of my university ensures better career opportunities compared with other universities } \\
\text { (SAT15). }\end{array}$ \\
\hline $\begin{array}{l}\text { University } \\
\text { infrastructures }\end{array}$ & $\begin{array}{l}\text {-I am satisfied with the resources provided by my university for academic education (Laboratory, computer } \\
\text { software, library database, .etc.) (SAT8). } \\
\text {-I am satisfied with the services/facilities (medical clinic, bathrooms, .etc.) provided by my university (SAT9). } \\
\text {-The required textbook/electronic books provided by my university are satisfactory (SAT10). } \\
\text {-I am proud of the good appearance of buildings and grounds of my university (SAT11). }\end{array}$ \\
\hline Support services & $\begin{array}{l}\text {-The non-academic activities provided by my university meet my need (SAT12). } \\
\text {-The support services provided by my university (transportation service, the student union, alumni,...... etc.) are } \\
\text { satisfactory (SAT13). } \\
\text {-I am pleased with the internal environment (resources, management, system, activities,.........etc.) of my } \\
\text { university (SAT14). }\end{array}$ \\
\hline Student loyalty (LAY) ( & $\begin{array}{l}\text { nades et al., 2013; Helgesen \& Nesset, 2007; Tomas, 2011) } \\
\text {-I recommend my university to friends/relatives to join it (LAY1). } \\
\text {-If I were to choose, I would select the same university again (LAY2). } \\
\text {-I would attend further education at my university (LAY3). } \\
\text {-I will continue supporting my university in the market/community (LAY4). } \\
\text {-If someone talks badly about my university, I will defend it (LAY5). }\end{array}$ \\
\hline Student commitment $(\mathrm{CO}$ & 1) (Riketta, 2002; Weibo et al., 2010) \\
\hline Continuous commitment & $\begin{array}{l}\text {-I would be very happy to complete my education at my university (COM1). } \\
\text {-I would increase my effort for my university to help it succeed (COM2). } \\
\text {-Making efforts to maintain a long-term commitment to my university is essential to me (COM3). }\end{array}$ \\
\hline Affective commitment & $\begin{array}{l}\text {-I belong to my university (COM4). } \\
\text {-My university has a great personal meaning (COM5). }\end{array}$ \\
\hline Student trust (TRS) (Gh & et al., 2016; Seppanen \& Blomqvist, 2007) \\
\hline Competence & -My university usually keeps its promises to students (TRS1). \\
\hline Integrity & -When my university makes an important decision, the students are usually the core of this decision (TRS2). \\
\hline Dependability/ & -My university usually fulfills the commitments it assumes (TRS3). \\
\hline Reliability & -My university solves students' complaints/problems with great concern (TRS4). \\
\hline Openness/ Honesty & -My university ensures transparency of information to students (TRS5). \\
\hline
\end{tabular}

\subsection{Data Collection Method}

A structured questionnaire to senior students in two faculties of management science at two private universities in Egypt is used to collect the research data. Except for the demographic variables, the 5-point Likert scale was 
used as a measurement for all of the dependent and independent variables. For all constructs, the measurements were selected from the relevant literature, as indicated in Table 1. The questionnaire was tested with a convenience sample of students twice and modified before using the final version.

\subsection{The Research Population and Sample}

Private universities in Egypt were chosen as the service context for this study. The reason for selecting this sector for the study is that the (1) university embodies an interesting implication for a research study in services marketing literature (Hilali et al., 2015; Kalenskaya et al., 2013), (2) private universities are strongly showing presence in the landscape of higher education in Egypt (Barsoum, 2014), and (3) there is a lot of academic discussions about treating the universities their students as customers approach with applying the marketing practices (e.g., Budd, 2017; Bunce et al., 2016; Chalcraft et al., 2015).

The number of private universities in Egypt is 23 universities in 2017 (Ministry of Higher Education- Egypt, 2017). Although it may be enough to choose one university as a case study, the researchers decided to choose two universities to make comparison between their results if required, also the researchers have access to these universities (in fact the comparison was made as a byproduct analysis and similarities exist between the results of the two cases).

The students' population consists of senior students who are close to graduation and have experience with their universities. They are divided into similar groups or classes in the two universities. A sample of 10 classes/groups consisting of 400 students was determined, as a sample size. The classes were selected randomly, group/cluster random sample.

\subsection{Data Collection}

The final version of the questionnaire was administered to 400 students in the two universities, The data collection process started on 29 April and continued till 11 May 2017. A total of 390 completed and usable questionnaires were obtained making $97.5 \%$ response rate. The sample consists of $63 \%$ male and $37 \%$ female, their age ranges between $20-22$ years $(85 \%)$ and more than half of the sample units was in the fourth level of their faculties $(62 \%)$ as only $38 \%$ of respondents were in the third level.

To assess the internal consistency reliability of the research measurements, the Cronbach's alpha coefficient was measured for each of the independent and dependent variables using SPSS 22 software. Table 2 shows that all Cronbach alpha values of the research variables were ranged between 0.78 to 0.89 , more than 0.70 (Nunnally, 1978). Thus, all measurements of the research variables are reliable and can be used for testing the research hypotheses.

Table 2. Cronbach's Alpha of the research variables

\begin{tabular}{lll}
\hline Variable & No. of items & Cronbach's Alpha \\
\hline Student citizenship behavior & 10 & 0.78 \\
Student satisfaction & 15 & 0.84 \\
Student loyalty & 5 & 0.89 \\
Student commitment & 5 & 0.85 \\
Student trust & 5 & 0.87 \\
\hline
\end{tabular}

\section{The Research Results and Testing of Hypotheses}

The statistical package for social sciences (SPSS 22) and the structural equation modeling (SEM) through AMOS (Analysis of Moment Structure) 24.0 were applied to test the three research hypotheses. SPSS was employed to determine the measurements of citizenship behavior by exploratory factor analysis and measure the Pearson's correlation among the four antecedent variables of student citizenship behavior. Amos was used to test the structural relationship between the citizenship behavior and its proposed antecedents: student satisfaction, loyalty, commitment, and trust.

To test hypothesis (1): student citizenship behavior in universities can be categorized in two voluntary behavior, cooperation and participation behavior, exploratory factor analysis (EFA) was performed based on principal components with varimax rotation by SPSS 22. The factor analysis applies to 10 items of student citizenship behavior. The measurements with eigenvalues exceeding 1 as well as the factor loadings above 0.30 were recognized significant (Hair et al., 1998). Table 3 shows the results of factor analysis by classifying the student citizenship into two factors. The value of KMO is determined as 0.818 and Bartlett's test of sphericity as 826.031, 
significant at 0.01 , that justifies the use of factor analysis. Six items were loaded on "voluntary cooperative behavior" factor with the variance of $27.5 \%$, while "voluntary participation behavior" which contributes a variance of $20 \%$ contained four items. The two factors together explain the cumulative variance of $47.5 \%$. This result supports the first hypothesis of this study as student citizenship behavior can be categorized in two voluntary performances in universities which are cooperation and participation behaviors.

Table 3. Categories of student citizenship behavior items

\begin{tabular}{lll}
\hline Items & Factor Loadings & Factors explained variance \\
\hline Factor 1: Voluntary cooperative behavior & & \\
-I completely follow my university procedures. & 0.715 & $27.50 \%$ \\
-I fully cooperate with my university staff. & 0.709 & \\
-I assist other students to use my university's service correctly. & 0.651 & 0.655 \\
-I usually protect my university facilities/equipment. & 0.649 & \\
-I help other students in my university when they need. & 0.479 & \\
-I share my opinion with university staff. & & \\
Factor 2: Voluntary participation behavior & 0.481 & $20 \%$ \\
-I am willing to wait longer to obtain a service from my university. & 0.553 \\
-I generally participate with the staff of my university to facilitate their jobs. & 0.827 \\
-I participate in events that support my university. & 0.773 & \\
-I provide information to my university even if I am not asked to do this. &
\end{tabular}

To test the second hypothesis of this study, the Bivariate Pearson correlation was used to test the interrelationship among student satisfaction, loyalty, commitment, and trust towards their universities. Table 4 summarizes a correlation matrix of these independent variables. Bivariate correlation result revealed that all student satisfaction, loyalty, commitment and trust measurements have a substantial relationship range from moderate to high correlations.

Table 4. Interrelationships among student satisfaction, loyalty, commitment, and trust

\begin{tabular}{|c|c|c|c|c|c|c|c|c|c|c|c|c|c|c|c|c|c|c|c|c|c|c|c|c|c|c|c|c|c|}
\hline & & & & & & & & & & & & & & orrelatans & & & & & & & & & & & & & & & \\
\hline & SAT1 & SAT2 & SAT3 & SAT4 & SATS & \begin{tabular}{|l|l} 
SAT6 \\
\end{tabular} & 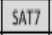 & \begin{tabular}{|l|l|} 
SATR \\
\end{tabular} & SAT9 & SAT10 & SAT11 & SAT12 & SAT13. & & & uY1 1 & LVY2 & uY3 & uYa & UYS & COM1 & $\operatorname{com}_{2} \mathrm{Cc}$ & $\mathrm{CON}_{3} \mathrm{CC}$ & & COMS I I & TRS1 & TRS2 & & TRSA TRS \\
\hline SAT1 & 1 & & & & & & & & & & & & & & & & & & & & & & & & & & & & \\
\hline SAT2 & $589^{\circ 4}$ & 1 & & & & & & & & & & & & & & & & & & & & & & & & & & & \\
\hline SAT3 & $396^{\circ "}$ & $5.533^{\circ *}$ & 1 & & & & & & & & & & & & & & & & & & & & & & & & & & \\
\hline SAT4 & $.410^{\circ 4}$ & $5.500^{\circ}$ & $461^{\circ *}$ & 1 & & & & & & & & & & & & & & & & & & & & & & & & & \\
\hline SATS & $.495^{\circ 4}$ & $.479^{* *}$ & $394^{\circ}$ & .354" & 1 & & & & & & & & & & & & & & & & & & & & & & & & \\
\hline SAT6 & $.429^{\circ 4}$ & $.444^{* \prime}$ & $330^{\circ}$ & $308^{* \prime}$ & . $571^{*}$ & 1 & & & & & & & & & & & & & & & & & & & & & & & \\
\hline SAT7 & $.461^{\circ 4}$ & ".407". & $346^{\circ}$ & $326^{\circ}$ & |. $407^{-4}$ & . $454^{\circ}$ & 1 & & & & & & & & & & & & & & & & & & & & & & \\
\hline SAT8 & $388^{\circ}$ & . 351 " & "311" & $2.254^{*}$ & $363^{\circ "}$ & $360^{\circ \circ}$ & $399^{*}$ & 1 & & & & & & & & & & & & & & & & & & & & & \\
\hline SAT9 & $.281^{\circ 4}$ & $3211^{*}$ & $307^{\circ}$ & $2188^{*}$ & $260^{\circ \circ}$ & $\mid 283^{\circ}$ & $313^{* *}$ & 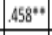 & 1 & & & & & & & & & & & & & & & & & & & & \\
\hline SAT10 & $261^{* 4}$ & $2.284^{\circ *}$ & $2286^{\circ}$ & $2.283^{*}$ & . $2511^{\circ}$ & $2.256^{\circ}$ & $314^{* *}$ & $.276^{\circ}$ & $.272^{*}$ & 1 & & & & & & & & & & & & & & & & & & & \\
\hline SAT11 & $249^{\circ 4}$ & $2.295^{*}$ & $\mid 287^{*}$ & $.229 "$ & . $355 \% "$ & $303^{\circ "}$ & $321^{*}$ & $312^{* *}$ & $373^{\circ *}$ & $.2122^{* *}$ & 1 & & & & & & & & & & & & & & & & & & \\
\hline SAT12 & $294^{\circ}$ & $3.355 " 0$ & "2273" & $2.275^{\circ}$ & . $3399^{\circ}$ & $302^{2 *}$ & $3377^{\circ}$ & 年 $287^{2}$ & $313^{* *}$ & . $250^{\circ}$ & $300^{\circ}$ & 1 & & & & & & & & & & & & & & & & & \\
\hline SAT13 & $318^{* 4}$ & $.378^{*}$ & $2276^{\circ}$ & $3355^{\circ}$ & $335 \%$ & $316^{\circ}$ & $355^{\circ}$ & $328^{\circ *}$ & $.360^{\circ *}$ & $.335^{* \prime}$ & $330^{\circ}$ & $3599^{\circ}$ & 1 & & & & & & & & & & & & & & & & \\
\hline SAT14 & $398^{* *}$ & $4.409^{* 0}$ & $\cdot 296^{\circ}$ & $2.261^{*}$ & $\mid .406^{\circ \prime}$ & . $3955^{\circ}$ & $366^{\circ *}$ & $3.38^{\circ *}$ & $374^{* *}$ & $.273^{* *}$ & $399^{\circ}$ & 3900 & . $43^{*}$ & 1 & & & & & & & & & & & & & & & \\
\hline SAT15 & $.397^{\circ}$ & $.428^{* *}$ & $381^{\circ}$ & $310^{\circ}$ & . $424^{\circ *}$ & 年 $456^{-1.6}$ & $.4266^{\circ}$ & . $399^{\circ *}$ & $.385^{\circ}$ & $324^{* *}$ & $351^{\circ}$ & $2922^{* \prime}$ & $316^{\circ *}$ & $.406^{\circ}=$ & 1 & & & & & & & & & & & & & & \\
\hline UYY1 & $470^{\circ}$ & .534 " & $386^{\circ}$ & $3722^{*}$ & . $504^{\circ}$ & $\mid .435^{\circ}$ & $\mid .402^{2 *}$ & .371" & $.340^{\circ *}$ & $.258^{* *}$ & $348^{\circ}$ & $317^{* *}$ & . $359^{\circ *}$ & $.455 \cdots-52$ & $628^{\circ}$ & 1 & & & & & & & & & & & & & \\
\hline ur2 & . $438^{\circ *}$ & $.485^{\circ}$ & $384^{\circ}$ & $333^{\circ}$ & . $4311^{\circ}$ & $364^{\circ *}$ & . $3355^{\circ}$ & $.274^{* 4}$ & $313^{*}$ & $312^{* *}$ & $317^{\circ}$ & $295^{*}$ & $.296^{\circ}$ & $.458^{\circ}=46$ & $468^{4 * 1} \cdot 6$ & $679^{\circ-}$ & 1 & & & & & & & & & & & & \\
\hline Lav3 & $.298^{\circ}$ & $3.392 " *$ & $366^{\circ}$ & $3155^{*}$ & . $359{ }^{\circ}$ & $314^{\circ *}$ & . $293^{\circ *}$ & $2.289^{* 4}$ & $314^{\circ "}$ & $.261^{* \prime}$ & $2400^{\circ}$ & $.278^{* \prime}$ & $310^{\circ}$ & $311^{\prime \prime}-34$ & $349^{*} \cdot 1.4$ & $472 * 5.5$ & $512^{* *}$ & 1 & & & & & & & & & & & \\
\hline UYY4 & $445^{\circ}$ & $5.501 " *$ & $4375^{\circ}$ & $337 "$ & . $455^{\circ}$ & $3922^{*}$ & $3199^{*}$ & . $306^{\circ "}$ & $307 "$ & $.154^{* *}$ & $320^{\circ}$ & $.297^{\circ *}$ & $334^{\circ}$ & $363^{\circ *}-37$ & $379+4.5$ & $590^{\circ *} .5$ & . $571^{\circ * 4}$ & $.414^{*}$ & 1 & & & & & & & & & & \\
\hline uYss & $374^{\circ}$ & $.417{ }^{*}$ & $300^{\circ}$ & $320^{\circ}$ & . $360^{\circ *}$ & $394^{\circ 0}$ & $344^{* *}$ & . $253^{\circ *}$ & $.228^{\circ *}$ & $.183^{* *}$ & $267^{\circ}$ & $295^{* 0}$ & $.247^{\circ}$ & $310^{\circ *} \cdot 40$ & $400^{* *} \cdot 5$ & $510^{\circ}$ & $4911^{\circ} .3$ & .381" & $.617^{\circ}$ & 1 & & & & & & & & & \\
\hline COM1 & $346^{\circ}$ & $.4322^{*}$ & $347^{\circ}$ & $2922^{\circ}$ & . $4.433^{\circ *}$ & $398^{\circ}$ & $329^{\circ}$ & $274^{* *}$ & $.336^{\circ}$ & $.231^{* *}$ & $399^{\circ}$ & $347^{* *}$. & . $351^{\circ}$ & $397 \% \cdot 43$ & $431 \times 4.5$ & $501 \% .5$ & $565^{\circ 0}$ & $.453^{\circ}$ & $565^{\circ}$ & $560^{\circ \circ}$ & 1 & & & & & & & & \\
\hline CoM 2 & $341^{\circ}$ & $3.396^{\circ}$ & $370^{\circ}$ & $1.318^{* *}$ & $377^{\circ}$ & $358^{\circ}$ & $337^{\circ}$ & $.254^{\circ \prime}$ & $.355^{\circ *}$ & $.235^{*}$ & $393^{\circ}$ & $304^{* \prime}$ & $390^{\circ}$ & $.343^{\circ \cdots} \cdot 43$ & $4322^{*}$ & $435^{\circ}-4$ & $461 * 4$ & $456^{40}$ & . $586^{\circ}$ & $5277^{\circ}$ & $.642^{* *}$ & 1 & & & & & & & \\
\hline Com 3 & $348^{\circ}$ & $3.360^{* \prime}$ & $2229^{\circ}$ & $2.226^{\circ \prime}$ & . $388^{\circ *}$ & $384^{\circ}$ & $338^{\circ *}$ & $324^{\circ \prime}$ & $.279^{*}$ & $.218^{* *}$ & $253^{\circ}$ & $.277^{\circ}$ & $.247^{\circ}$ & $329^{\circ} \cdot 44$ & $44^{4 *} \cdot 3$ & $366^{\circ}=4$ & $450^{\circ *} .3$ & $366^{\circ *}$ & $397^{\circ}$ & $.376^{\circ *}$ & S. $5955^{5}$ & $532^{\circ}$ & 1 & & & & & & \\
\hline cons & $3555^{\circ}$ & " & $4300^{\circ}$ & $4.224^{* 1}$ & . $388^{\circ}$ & 年 & . $333^{\circ *}$ & $2.288^{\circ 4}$ & $.292^{\circ}$ & $.185^{\circ}$ & $299^{\circ}$ & $.281^{\circ \prime}$ & . $320^{\circ}$ & $355 \% 43$ & $431^{\circ}$ & $465^{\circ *} .5$ & $513^{* *} \cdot 3$ & $.358^{\circ "}$ & . $497{ }^{\circ}$ & . $479^{\circ *}$ & $.507^{\circ-5} 5$ & $534^{\circ} \cdot .5$ & $.541^{\prime \prime}$ & 1 & & & & & \\
\hline Coms & $.425^{\circ}$ & $.481^{*}$ & $350^{\circ}$ & $3.325 "$ & 年 $.45 \%$ & $\mid .411^{* *}$ & $347^{\circ "}$ & $338^{\circ \prime}$ & $.382^{\circ}$ & $.283^{\circ}$ & $328^{\circ}$ & $322^{* \prime}$ & . & $.404^{\circ} \cdot 44$ & $44^{4 *} .5$ & $500^{* *} .5$ & $579^{\circ} .4$ & $.44^{\prime \prime}$ & $525^{\circ}$ & $.46^{\circ}$ & $.488^{\circ-}$ & $4991^{\circ} .5$ & $506^{\circ "}=6$ & & 1 & & & & \\
\hline TRS1 & $.352^{*}$ & $.4466^{\circ}$ & $345^{*}$ & $4.351 "$ & . $382^{2 *}$ & $3622^{\circ}$ & $391^{* *}$ & $315^{* *}$ & $347^{\circ}$ & $.275^{* *}$ & $271^{\circ}$ & $316^{\prime \prime}$ & . $416^{\circ *}$ & $371 \%=36$ & $367^{\circ} \cdot 4$ & $471^{*} .4$ & $471 \times 3$ & $386^{\circ}$ & . $369^{\circ *}$ & $328^{\circ 0}$ & $372^{*-3} 3$ & $383^{\circ}+3$ & $366^{\circ}=$ & & $565^{\circ "}$ & 1 & & & \\
\hline TRS2 & $309^{4}$ & $3.374^{* *}$ & $2298^{\circ}$ & $2.287^{\circ}$ & 年 $358^{\circ}$ & $305^{\circ *}$ & $330^{\circ-}$ & $2.290^{\circ *}$ & $.338^{\circ "}$ & $.329^{* *}$ & $298^{\circ}$ & $345^{* \prime}$ & $376^{\circ}$ & $324^{\circ}=33$ & $3399^{4}-3$ & $381^{* *} .3$ & $377^{\circ} \cdot 3$ & $376^{\circ}$ & . $416^{\circ}$ & $299^{\circ}$ & $.433^{\circ *}$ & $414^{\circ} \cdot 3$ & $369^{\circ *}-3$ & & $510^{\circ *} \cdot 6$ & $624^{\circ *}$ & 1 & & \\
\hline TRS3 & $347^{\circ "}$ & $.410^{\circ *}$ & $300^{\circ}$ & $4.344^{* 0}$ & $368^{\circ "}$ & $327^{\circ}$ & $377^{\circ}$ & $.329^{* *}$ & $.410^{\circ "}$ & $.284^{* *}$ & $319^{\circ}$ & $.294^{\prime \prime}$ & $385^{\circ}$ & $3993^{\circ}-37$ & & $421^{* *}$ & $402 \cdots 3$ & .358" & . $409^{\circ}$. & . $346^{\circ}$ & $375^{* 1} 3$ & $398^{\circ} .4$ & $408^{\circ} \cdot 3$ & & $527^{\circ} \cdot 5$ & $.584^{\circ} \cdot 6$ & & 1 & \\
\hline TRS4 & $342^{*}$ & . $3.384^{\circ}$ & $3997^{\circ}$ & . $3.371^{* *}$ & $.315^{* *}$ & $2.290^{*}$ & . $3355^{\circ}$ & $2.294^{\circ \prime}$ & $.353^{*}$ & $326^{\circ *}$ & $262^{\circ}$ & $320^{\circ *}$. & . $360^{\circ}$ & $.343^{\circ *}-34$ & $344^{4}-1.3$ & $375^{* 1} .4$ & $451^{\circ *} .4$ & $.412^{*}$ & . $356^{\circ}$ & $2777^{\circ}$ & $.391^{* 1}$ & $399^{\circ} \cdot 3$ & $362^{\circ *} 3$ & $364^{*}+51$ & $513^{* *} .6$ & $.604^{*} .5$ & & & \\
\hline TRSS & $270^{\circ}$ & $3.344^{* 0}$ & $\mid 350^{\circ}$ & d.282"* & 年 & $2.267^{\circ}$ & . $2.275^{\circ}$ & $.267^{* 4}$ & $319^{* *}$ & $.276^{\circ *}$ & $228^{\circ}$ & $219^{* *}$ & . $295^{\circ}$ & $274^{*} \cdot 30$ & & & $371 \times 3$ & $302^{\circ *}$ & $338^{\circ}$ & $229^{\circ}$ & $316^{\circ 1}$ & & $352^{\circ *}=3$ & & & $548^{\circ *} .4$ & & & $599^{*}$ \\
\hline
\end{tabular}


The correlation coefficients between student satisfaction and their loyalty are significant ( $p$-value $0.000<0.01$ ) and positive (direct), ranges from 0.183 to 0.534 . Additionally, student satisfaction is moderately and positively correlated with student trust (Pearson correlation is from 0.219 to $0.446, p \leq 0.01$ ) and student commitment (Pearson correlation is 0.185 to $0.457, p \leq 0.01$. Student loyalty is highly correlated with student commitment to a continuous relationship with their universities with correlation coefficients between 0.358 to $0.586, p \leq 0.01$. The correlation coefficients for student loyalty and student trust are moderately between 0.229 to $0.471, p \leq 0.01$. Finally, a strong and significant correlation between student commitment and student trust is shown ranging from 0.329 to 0.565 with $p \leq 0.01$. These results provide support for the second hypothesis as significant interrelationships exist between all antecedents of student citizenship behavior.

To test the third hypothesis, the relationship between student satisfaction, loyalty, commitment, and trust and student citizenship behavior AMOS version 24.0 was used to verify the structural equation modeling (SEM). The maximum likelihood, the standard factor loading and t-value of the path coefficient are used to analyze the theoretical model for the goodness of fit and determine the path strengths and directions and the significance levels of the research variables (Jayasinghe-Mudalige et al., 2012). First, a confirmatory factor analysis (CFA) of the 40 items, composing the 10 dimensions of student citizenship behavior scale, and 30 items of the antecedents of student citizenship behavior were applied using Amos 24.0. The results demonstrate that two items were low standardized regression weights lower than the suggested value (.50). One item for student citizenship behavior (CCB4) and the second was for student satisfaction (SAT10). Therefore, these two items were eliminated from further analysis. The remaining items were then examined further to determine that the research model fits. The chi-square value of the research model is $\mathrm{x}^{2}=787.386, p=0.000$, suggesting inadequately the hypothesized model's fit to data. However, the literature on model fit indices, reports various other indices that should be utilized to reflect the model fit than the chi-square statistics (e.g., Byrne, 2010; Hooper et al., 2008; Lei \& Wu, 2007). The output of these indices in the research model are: $\mathrm{CFI}=0.973$; GFI $=0.91$; $\mathrm{AGFI}=0.930$; PGFI $=$ $0.76 ; \mathrm{RMR}=0.048 ; \mathrm{TLI}=0.96 ; \mathrm{NFI}=0.96 ; \mathrm{RFI}=0.95 ; \mathrm{RMSEA}=0.048$. All these values exceed the standard goodness of fit, reflecting a reasonable fit of the research measurement model with data.

Next, for assessing the construct reliability of the measurement model, the composite reliability is measured (Peterson \& Kim, 2013). For all the research variables, composite reliability was between 0.85 and 0.94 , exceeds 0.70 (Table 5). The convergent validity of the research model is determined by considering the significance of the standardized factor loadings between the measurements and their particular variables (Lei \& Wu, 2007). For the research measurement model, the measurements of all constructs were significant $(p=0.001)$; as shown in Table 5. The factor loadings of all research variables are from 0.60 to 0.90 , exceeds the suggested value $(0.50)$. Additionally, the average variance extracted (AVE) was measured to examine the convergent validity of the research model. The values of AVE for all constructs were all higher than 0.50 (Hoyle, 2012). Moreover, according to Fornell \& Larker (1981), the measurement model has discriminant validity when the square root of the average variance (AVE) of each variable is greater than the correlations between that variable and any other variable in the model. As shown in Table 6, the variance extracted from each research variable conforms to this standard, implying the appropriate discriminant validity for the research model. Therefore, according to the previous results of the research measurement model, all the variables were appropriate for testing the proposed model.

Table 5. Measurement model resulting from confirmatory factor analysis (CFA)

\begin{tabular}{|c|c|c|c|c|}
\hline Construct & Standardized factor loadings (t-value) & Critical ratio & $\mathrm{CR}$ & AVE \\
\hline \multicolumn{3}{|c|}{ Student citizenship behavior } & \multirow{11}{*}{0.92} & \multirow{11}{*}{0.57} \\
\hline SCB1 & 0.89 & & & \\
\hline SCB2 & 0.87 & $8.29(* * *)$ & & \\
\hline SCB3 & 0.76 & $7.88(* * *)$ & & \\
\hline $\mathrm{SCB} 4^{(\mathrm{a})}$ & Deleted & & & \\
\hline SCB5 & 0.67 & $7.66(* * *)$ & & \\
\hline SCB6 & 0.69 & $8.40(* * *)$ & & \\
\hline SCB7 & 0.71 & $8.50(* * *)$ & & \\
\hline SCB8 & 0.67 & $8.27(* * *)$ & & \\
\hline SCB9 & 0.61 & $7.22(* * *)$ & & \\
\hline SCB10 & 0.84 & $7.60(* * *)$ & & \\
\hline \multicolumn{3}{|c|}{ Student Satisfaction } & \multirow[t]{3}{*}{0.94} & \multirow[t]{3}{*}{0.55} \\
\hline SAT1 & 0.67 & & & \\
\hline SAT2 & 0.90 & $12.75(* * *)$ & & \\
\hline
\end{tabular}




\begin{tabular}{|c|c|c|c|c|}
\hline SAT3 & 0.60 & $10.77(* * *)$ & & \\
\hline SAT4 & 0.87 & $10.15(* * *)$ & & \\
\hline SAT5 & 0.68 & $12.01(* * *)$ & & \\
\hline SAT6 & 0.63 & $11.36(* * *)$ & & \\
\hline SAT7 & 0.62 & $11.08(* * *)$ & & \\
\hline SAT8 & 0.78 & $10.15(* * *)$ & & \\
\hline SAT9 & 0.66 & $9.58(* * *)$ & & \\
\hline $\operatorname{SAT} 10^{(\mathrm{a})}$ & Deleted & & & \\
\hline SAT11 & 0.84 & $9.27(* * *)$ & & \\
\hline SAT12 & 0.90 & $9.37(* * *)$ & & \\
\hline SAT13 & 0.83 & $10.17(* * *)$ & & \\
\hline SAT14 & 0.62 & $11.10(* * *)$ & & \\
\hline SAT15 & 0.65 & $11.58(* * *)$ & & \\
\hline Student I & & & 0.86 & 0.55 \\
\hline LAY1 & 0.82 & & & \\
\hline LAY2 & 0.79 & $16.25(* * *)$ & & \\
\hline LAY3 & 0.61 & $12.17(* * *)$ & & \\
\hline LAY4 & 0.77 & $15.93(* * *)$ & & \\
\hline LAY5 & 0.69 & $14.08(* * *)$ & & \\
\hline \multicolumn{2}{|c|}{ Student commitment } & & 0.85 & 0.55 \\
\hline COM1 & 0.75 & & & \\
\hline COM2 & 0.74 & $14.48(* * *)$ & & \\
\hline COM3 & 0.67 & $12.89(* * *)$ & & \\
\hline COM4 & 0.74 & $14.29(* * *)$ & & \\
\hline COM5 & 0.81 & $14.89(* * *)$ & & \\
\hline Student $\mathrm{t}$ & & & 0.87 & 0.57 \\
\hline TRS1 & 0.79 & & & \\
\hline TRS2 & 0.77 & $15.94(* * *)$ & & \\
\hline TRS3 & 0.78 & $16.14(* * *)$ & & \\
\hline TRS4 & 0.76 & $15.66(* * *)$ & & \\
\hline TRS5 & 0.68 & $13.68(* * *)$ & & \\
\hline
\end{tabular}

Note. CR, composite reliability; AVE, average variance extracted, $* * * p 0.001 ; N=390$.

-CCB- student citizenship behavior items, SAT- student satisfaction items, LAY- student loyalty, COM- student commitment, and TRS- student trust.

-(a): items lacked sufficient loading estimate less than 0.40 and eliminated from further analysis.

Table 6. Construct intercorrelations, means, and standard deviation

\begin{tabular}{llllllll}
\hline & M & SD & $\mathbf{1}$ & $\mathbf{2}$ & $\mathbf{3}$ & $\mathbf{4}$ & $\mathbf{5}$ \\
\hline 1. Student citizenship behavior & 3.71 & 0.59 & $\mathbf{0 . 8 2}$ & & & & \\
2. Student satisfaction & 3.36 & 0.66 & $0.52^{* *}$ & $\mathbf{0 . 8 1}$ & & & \\
3. Student loyalty & 3.44 & 0.87 & $0.49^{* *}$ & $0.71^{* *}$ & $\mathbf{0 . 7 4}$ & & \\
4. Student commitment & 3.52 & 0.82 & $0.44^{* *}$ & $0.69^{* *}$ & $0.63^{* *}$ & $\mathbf{0 . 7 3}$ & \\
5. Student trust & 3.16 & 0.87 & $0.41^{* *}$ & $0.65^{* *}$ & $0.58^{* *}$ & $0.63^{* *}$ & 0.76 \\
\hline
\end{tabular}

Note. $\mathrm{n}=390 ; *^{*} \mathrm{p}=0.01 ; \mathrm{M}=$ Mean; $\mathrm{SD}=$ Standard deviation. The square root of AVE for discriminant validity is in parentheses along the diagonal.

Furthermore, to test the multicollinearity between the independent variables of the model, the variance inflation factor (VIF) was used (Diamantopoulos \& Winklhofer, 2001). The variance inflation factors (VIFs) were calculated using SPSS. As indicated in Table 7, the results of this test suggested no multicollinearity between the antecedents of citizenship behavior. In addition, the variance inflation factor (VIF) was found less than the threshold limit of 5; for all the items, the highest variance inflation factor (VIF) had a value of 2.604. So multicollinearity does not represent a problem for the analysis. 
Table 7. The results of collinearity test of the independent variables

\begin{tabular}{ll}
\hline Independent variables & VIF \\
Student satisfaction & \\
\hline SAT1 & 1.625 \\
SAT2 & 2.161 \\
SAT3 & 1.714 \\
SAT4 & 1.629 \\
SAT5 & 1.949 \\
SAT6 & 1.818 \\
SAT7 & 1.603 \\
SAT8 & 1.572 \\
SAT9 & 1.605 \\
SAT11 & 1.439 \\
SAT12 & 1.408 \\
SAT13 & 1.638 \\
SAT14 & 1.725 \\
SAT15 & 1.837 \\
Student Loyalty & \\
LAY1 & 2.604 \\
LAY2 & 2.73 \\
LAY3 & 1.631 \\
LAY4 & 2.512 \\
LAY5 & 2.05 \\
Student commitment & \\
COM1 & \\
COM2 & \\
COM3 & 2.346 \\
COM4 & 2.463 \\
COM5 & 1.91 \\
Student trust & 2.131 \\
TRS1 & 2.52 \\
TRS2 & \\
TRS3 & 2.429 \\
TRS4 & 2.325 \\
TRS5 & 2.318 \\
Factor & 2.235 \\
& 1.787 \\
\hline
\end{tabular}

Note. *VIF: Variance Inflation Factor.

Finally, in terms of testing the proposed linkages between the antecedents of student citizenship behavior and citizenship behavior measurements, standardized weights $(\beta)$ result from Amos analysis were examined. Table 8 shows that two relationships were supported; student satisfaction and loyalty, as they have significant, positive and direct relationships with student citizenship behavior. Student loyalty has the strongest influence on student citizenship behavior $(\beta=0.425, p<0.001)$ followed by student satisfaction $(\beta=0.361, p<0.001)$. The relative contributions of loyalty and satisfaction variables to student citizenship behavior are $43 \%$ and $36 \%$, respectively. However, the results indicate that the effect of student commitment and student trust are not significant $p$-value and very low standard coefficients of $(\beta=0.007),(\beta=0.003)$. Therefore, the third hypothesis is partially accepted in supporting two antecedents of student citizenship behavior in universities.

Table 8. The relationship between student citizenship behavior and its antecedents' results

\begin{tabular}{lllll}
\hline & $\beta$ & S.E. & C.R. & Path \\
\hline Satisfaction $\rightarrow$ student citizenship behavior & 0.361 & 0.084 & $2.547^{* *}$ & Supported \\
Loyalty $\rightarrow$ student citizenship behavior & 0.425 & 0.091 & $2.202^{*}$ & Supported \\
Commitment $\rightarrow$ student citizenship behavior & 0.007 & 0.103 & $1.327 \mathrm{~ns}$ & Not supported \\
Trust $\rightarrow$ student citizenship behavior & 0.003 & 0.045 & $0.34 \mathrm{~ns}$ & Not supported \\
\hline standardized weight, S.E $=$ standard error, C.R. $=$ critical ratio. ${ }^{* *} \mathrm{p}=0.01 ;{ }^{*} \mathrm{p}=0: 05, \mathrm{~ns}=$ not significant.
\end{tabular}

\section{The Research Discussion}

It can be concluded that: first, the student citizenship behavior contains two types of voluntary behavior 
conducted by students to support universities in their roles. The first type of behavior is voluntary cooperative behavior in which students cooperate with university staff (academic and administrative staff) in providing effective educational services to their students by following the university rules and procedures, protecting the university facilities and contributing constructive suggestions to improve the educational services. As well, the students provide voluntary cooperative behavior to their colleagues/other students in the university through encouraging and explaining to them how to use the university services correctly and providing all help to them when they need. The second type of voluntary behavior is voluntary participation behavior with the university staff to facilitate their jobs and make their roles easier, participating and supporting events organized by their university to students and community (Educational, economics, social events,.... etc.), and providing helpful feedback and information that support their university to improve its educational services.

Second, the correlation between student satisfaction, loyalty, trust, and commitment indicates strong interrelationships between student loyalty and commitment. The results show that loyal and committed students desire to develop a continuous relationship with their universities during the educational life and even after they graduate. The highest correlation exists between satisfaction and loyalty, students who are satisfied with the quality of academic and administrative staff and the role of their universities to provide career opportunities in the market tend to stay loyal to their universities by recommending the universities to friends /relatives to join it, continue to have a relationship in the near future by further education in the university, continue supporting the university in the community and spread positive word of mouth about their universities. Finally, the results revealed that the highest and significant relationship exists between student commitment and trust. Students committed to their universities trust its competences and promises; they perceive that the university takes the educational decisions that are useful to their academic and social system to students, solves their complaints/ problems with great concern, and ensures the transparency of information to students. These results confirm the empirical support provided by other studies of Anaza \& Zhao (2013), Lee et al. (2014), and Ponnusamy \& Ho (2015).

Third, the result of structural equation modeling suggested that loyalty is an important and the strongest antecedent of all dimensions of student citizenship behavior in universities. Loyal students through their voluntary positive behavior provide some sort of strategic competitive advantage for their universities and may support their universities through spreading positive word of mouth about their universities. Also, they usually have interests to develop long-term relationships with their universities through attending new courses or further education in the future and supporting their universities in the community. This result concurs with the findings of earlier studies of Abbas et al. (2011), Anaza \& Zhao (2013), and Bove et al. (2009).

Another important antecedent to student citizenship behavior is student satisfaction. The results revealed that satisfied students with the academic and social system of their universities are willing to engage in related voluntary and discretionary behavior above their specified roles because of happiness. Additionally, the study revealed that students are satisfied with the educational and social life of their universities (e.g., the good communications with the university staff, and supportive services and the internal environment of their universities). Finally, they are satisfied with the career opportunities provided by their universities. Also, it was found that satisfaction with core educational services provided by universities through the qualified academic staff of the university and the efficient educational program are relatively the highest significant factor enhancing student citizenship behavior in universities. The results of this study consistent with the results of previous studies of Chen et al. (2015), Chiu et al. (2015), Groth (2005), Lee et al. (2014), and Ponnusamy \& Ho (2015).

The study results demonstrate that students are motivated to conduct extra behavior when only they are loyal and satisfied with university's educational and social systems. Student commitment and trust have no direct influence on student citizenship behavior. These variables help in developing the continuous and long-term relationship between students and their universities. This result is consistent with other previous studies such as Anaza \& Zhao (2013) and Chen et al.( 2015).

\section{Managerial Implications and Recommendations}

The findings of this research highlight a number of important implications for universities. Universities should consider students as valuable resources, in terms of both their formal roles and voluntary behavior that support the educational environment of a university. Furthermore, they should recognize that students conduct their voluntary behavior without thinking of getting a salary, bonus or any monetary or nonmonetary incentives, but they volunteer to support their universities. Moreover, universities must develop appropriate marketing communication systems specifically, direct personal interactions with their students to inform them about their voluntary behavior and the extent of this behavior to enhance the educational and social life of their universities. 
The findings suggest that not only do the academic and administrative staff benefit from student citizenship behavior through facilitating and supporting their roles in providing effective educational services but also, other students will benefit from this voluntary behavior as they will be assisted by their collogues and will be using the university's services correctly. Universities could utilize this finding to formulate strategies to induce student citizenship behavior in the educational environment. Additionally, the dimensions of citizenship behavior suggested in the study; cooperation and participation behavior can aid universities in selecting students to develop and facilitate this extra role behavior.

According to the results, satisfied and loyal play an important role through their citizenship behavior, therefore, universities should consider the appropriate motivational systems to students who provide citizenship behavior to staff and/or other students to enhance the university educational services. Furthermore, universities should make their students satisfied with the educational and social services to develop their loyalty towards their universities, therefore, fostering the possibility of students to involve citizenship behavior.

\section{The Research Limitations and Suggestions for Future Research}

First, the present research focused on the effects of four primary factors on student citizenship behavior only; therefore, other factors such as student perception of their university service quality, reputation, and justice can be tested by future research. Second, this study measured the citizenship behavior from only the student perspective, therefore, future researchers can investigate the relationship between these behavior and other variables such as organizational citizenship behavior of academic and administrative staffs of universities. Third, the current study tested the interrelationships among student satisfaction, loyalty, commitment, and trust without testing the causality of these interrelationships. Future studies may test the causal interrelationship to determine which factor influences others and to what extent this causality influences the customer/student citizenship behavior. Fourth, the study views the different types of voluntary and discretionary behavior as a single construct. Future studies can test the extent to which the antecedents affect each type of student citizenship behavior. Fifth, further, possible moderators of student citizenship behavior may be examined in future research such as student demographic characteristics like gender, age, and the educational level which may play an important role in shaping a student's citizenship behavior. Sixth, although the study found a significant relationship between satisfaction, loyalty, commitment, and trust, it does not show any impact of student commitment and trust on student citizenship behavior. Further study can examine the role of these two variables as mediator variables in influencing the student citizenship behavior. Seventh, the results are limited to students in private universities, future research can compare between public and private universities. Finally, the outcomes of customer citizenship behavior need further studies.

\section{References}

Abbas, A., Hasan, S., Mehdi, B., \& Abbasi, R. (2011). A study of factors effecting customer citizenship behavior. Interdisciplinary Journal of Contemporary Research in Business, 3(1), 1170-1191.

Abbasi, A., \& Zivarmoghbeli, A. E. (2014). Survey impact bank reputation in customer citizenship behavior, Case study of customer Agri bank of Kerman (Iran): Appraisal and testing of model by Amos graphics. Technical Journal of Engineering and Applied Sciences, 4(4), 359-369.

Abolfathi, A., Tollabi, Z., \& Pourashrf, Y. A. (2013). The study of the relationship between perceived quality of electronic services and Melli bank customers' citizenship behavior in Ilam Province. European Online Journal of Natural and Social Sciences, 2(3), 1159-1168.

Aggarwal, N. (2013). Revising dimensions of customer citizenship behavior: A survey in Indian context. Pacific Business Review International, 6(3), 5-13.

Aggarwal, N., \& Soch, H. (2013). Exploratory factor analysis of customer voluntary behavior in Indian retail sector- An empirical study. Indian Journal of Applied Research, 3(9), 34-36. https://doi.org/10.15373/2249555X/SEPT2013/109

Anaza, N., \& Zhao, J. (2013). Encounter-based antecedents of e-customer citizenship behaviors. Journal of Service Marketing, 27(2), 130-140. https://doi.org/10.1108/08876041311309252

Aurier, P., \& Goala, G. N. (2010). The differing and mediating roles of trust and relationship commitment in service relationship maintenance and development. Journal of the Academy of Marketing Science, 38, 303-325. https://doi.org/10.1007/s11747-009-0163-z

Balaji, M. S. (2015). Investing in customer loyalty: The moderating role of relational characteristics. Service Business, 9, 17-40. https://doi.org/10.1007/s11628-013-0213-y 
Barsoum, G. (2014). The challenges of private higher education in Egypt. Economic Research Forum, Egypt.

Bartikowski, B., \& Walsh, G. (2011). Investigating mediators between corporate reputation and customer citizenship behaviors. Journal of Business Research, 64, 39-44. https://doi.org/10.1016/j.jbusres.2009.09.018

Bettencourt, L. A. (1997). Customer voluntary performance: Customers as partners in service delivery. Journal of Retailing, 73(3), 383-406. https://doi.org/10.1016/S0022-4359(97)90024-5

Bove, L. L., Pervan, S. J., Beaty, S. E., \& Shiu, E. (2009). Service worker role in encouraging customer organizational citizenship behaviors. Journal of Business Research, 62, 698-705. https://doi.org/10.1016/j.jbusres.2008.07.003

Budd, R. (2017). Understanding orientations towards higher education in Germany and England: Problematizing the notion of "student as customer". Higher Education, 73, 23-37. https://doi.org/10.1007/s10734-015-9977-4

Bunce, L., Baird, A., \& Jones, S. E. (2016). The student-as-consumer approach in higher education and its effect on academic performance. Studies in Higher Education, 1-21.

Byrne, B. (2010). Structural equation modeling with AMOS: Basic concepts, applications, and programming. New York: Routledge Taylor \& Francis Group.

Chalcraft, D., Hilton, T., \& Hughes, T. (2015). Customer, collaborator or co-creator? What is the role of student in a changing higher education servicescape? Journal of Marketing for Higher Education, 25(1), 1-4. https://doi.org/10.1080/08841241.2015.1044790

Chen, K. H., Hsieh, K. J., Chang, F. H., \& Chen, N. C. (2015). The customer citizenship behaviors of food blog users. Sustainability, 7, 12502-12520. https://doi.org/10.3390/su70912502

Chiu, W., Kwag, M. S., \& Bae, J. S. (2015). Customers as partial employees: The influences of satisfaction and commitment on customer citizenship behavior in fitness centers. Journal of Physical Education and Sport, 15(4), 627-633.

Curth, S., Uhrich, S., \& Benkenstein, M. (2014). How commitment to fellow customers affects the customer-firm relationship and customer citizenship behavior. Journal of Services Marketing, 28(2), 147-158. https://doi.org/10.1108/JSM-08-2012-0145

Dai, Y. D., Chen, K. Y., \& Wu, S. C. (2014). Relationship quality and customer voluntary performance behavior: A perspective of social exchange. 4th Annual International Conference on Business Strategy and Organizational Behavior Proceedings, p. 68. https://doi.org/10.5176/2251-1970_THoR14.04

Di, E., Huang, C. J., Chen, I. H., \& Yu, T. C. (2010). Organization Justice and customer citizenship behavior of retail industries. The Service Industries Journal, 30(11), 1919-1934. https://doi.org/10.1080/02642060802627533

Diamantopoulos, A., \& Winklhofer, H. M. (2001). Index construction with formative indicators: An alternative to scale development. Journal of Marketing Research, 38(2), 269-277. https://doi.org/10.1509/jmkr.38.2.269.18845

El-Manstrly, D., Paton, R., Veloutsou, C., \& Moutinho, L. (2011). An empirical investigation of the relative effect of trust and switching costs on service loyalty in the UK retail banking industry. Journal of Financial Services Marketing, 15(2), 101-110. https://doi.org/10.1057/fsm.2011.9

Ercsey, I. (2016). Customer participation: Mandatory or voluntary behavior? Club of Economics in Miskole TMP, 12(1), 27-36. https://doi.org/10.18096/TMP.2016.01.04

Fernades, C., Ross, K., \& Meraj, M. (2013). Understanding student satisfaction and loyalty in the UAE HE sector. International Journal of Educational Management, 27(6), 613-630. https://doi.org/10.1108/IJEM-07-2012-0082

Flint, D., Blocker, C. P., \& Boutin, P. J. (2011). Customer value and anticipation, customer satisfaction and loyalty: An empirical examination. Industrial Marketing Management, 40(2), 219-230. https://doi.org/10.1016/j.indmarman.2010.06.034

Fornell, C., \& Larcker, D. F. (1981). Evaluating structural equation models with unobservable and measurement error. Journal of Marketing Research, 18(1), 39-50. https://doi.org/10.2307/3151312

Ghosh, A. K., Whipple, T., \& Bryan, G. A. (2016). Student trust and its antecedents in high education. The 
Journal of Higher Education, 72(3), 322-340. https://doi.org/10.1080/00221546.2001.11777097

Groth, M. (2005). Customers as good soldiers: Examining citizenship behaviors in Internet service deliveries. Journal of Management, 31(1), 7-27. https://doi.org/10.1177/0149206304271375

Hair, J. F., Tatham, R. L., Anderson, R., \& Black, W. (1998). Multivariate data analysis. UK: Prentice Hall- 5th edition.

Helgesen, Q., \& Nesset, E. (2007). What accounts for students' loyalty? Some field study evidence. International Journal of Educational Management, 21(2), 126-143. https://doi.org/10.1108/09513540710729926

Henning-Thurau, T., Langer, M. F., \& Hansen, U. (2001). Modeling and managing student loyalty: An approach based on the concept of relationship quality. Journal of Service Research, 3(4), 331-344. https://doi.org/10.1177/109467050134006

Hilali, N., Al-Jaber, S., \& Hussein, L. (2015). Students' satisfaction and achievement and absorption capacity in higher education. Procedia-Social and Behavioral Sciences, 177, 420-427. https://doi.org/10.1016/j.sbspro.2015.02.384

Hooper, D., Coughlan, J., \& Mullen, M. R. (2008). Structural equation modeling: Guidelines for determining fit. The Electronic Journal of Business Research, 6(1), 53-60.

Hoyle, R. H. (2012). Handbook of structural equation modeling. New York: The Guilford Press.

Icli, G. E., \& Anil, N. K. (2014). The HEDQUAL scale: A new measurement scale of service quality for MBA programs in higher education. South African Journal of Business Management, 45(3), 31-44.

Jayasinghe-Mudalige, U. K., Udugama, J. M., \& Ikram, S. M. (2012). Use of structural equation modeling techniques to overcome the empirical issues associated with quantification of attitudes and perceptions. Sri Lankan Journal of Applied Statistics, 13, 15-37. https://doi.org/10.4038/sljastats.v13i0.5122

Johnson, J. W., \& Rapp, A. (2010). A more comprehensive understanding and a measure of customer-helping behavior. Journal of Business Research, 63, 787-792. https://doi.org/10.1016/j.jbusres.2008.03.006

Jung, J. H., \& Yoo, J. J. (2017). Customer-to-customer interactions on customer citizenship behavior. Service Business, 11, 117-139. https://doi.org/10.1007/s11628-016-0304-7

Kalenskaya, N., Gafurov, I., \& Novenkova, A. (2013). Marketing of educational services: Research on service providers satisfaction. Procedia Economics and Finance, 5, 368-376. https://doi.org/10.1016/S2212-5671(13)00044-0

Kaur, H., \& Soch, H. (2013). Mediating roles of commitment and corporate image in the formation of customer loyalty. Journal of Indian Business Research, 5(1), 33-51. https://doi.org/10.1108/17554191311303376

Kotze, T. G., \& Plessis, P. J. (2003). Students as "co-producer" of education: A proposed model of student socialization and participation at tertiary institutions. Quality Assurance in Education, 11(4), 186-201. https://doi.org/10.1108/09684880310501377

Lara, P. Z. M. (2015). Hotels' fair treatment of staff and service satisfaction as causes of customer citizenship behavior (CCIB). The 2015 WEI International Academic Conference Proceedings, The West East Institute, 181-183.

Lee, Y. K., Choi, B. H., Kim, D. J., \& Hyun, S. S. (2014). Relational benefits, their consequences, and customer membership types. The Service Industries Journal, 34(3), 230-250. https://doi.org/10.1080/02642069.2013.763927

Lei, P. W., \& Wu, Q. (2007). Introduction to structural equation modeling: Issues and practical considerations. Educational Measurement Issues and Practices, 33-43. https://doi.org/10.1111/j.1745-3992.2007.00099.x

Macintosh, G. (2002). Perceived risk and outcome differences in multi-level service relationships. Journal of Service Marketing, 16(2), 143-157. https://doi.org/10.1108/08876040210422682

Morgan, R. M., \& Hunt, S. D. (1994). The commitment-trust theory of relationship marketing. Journal of Marketing, 58(3), 20-38. https://doi.org/10.2307/1252308

Mosavi, S. A., \& Ghaedi, M. (2012). A survey on the relationships between customer satisfaction, image, trust and customer advocacy behavior. African Journal of Business Management, 6(8), 2897-2910.

Ministry of Higher Education- Egypt. (2017). Retrieved from http://www.mohe-casm.edu.eg

Noyan, F., \& Simsek, G. G. (2014). The antecedents of customer loyalty. Procedia-Social and Behavioral 
Sciences, 109, 1220-1224. https://doi.org/10.1016/j.sbspro.2013.12.615

Nunnally, J. C. (1978). Assessment of reliability. Psychometric theory. New York: McGraw-Hill.

Peterson, R. A., \& Kim, Y. (2013). On the relationship between coefficient alpha and composite reliability. Journal of Applied Psychology, 98(1), 194-198. https://doi.org/10.1037/a0030767

Picon, A., Castro, I., \& Roldan, J. L. (2014). The relationship between satisfaction and loyalty: A mediator analysis. Journal of Business Research, 67, 745-751. https://doi.org/10.1016/j.jbusres.2013.11.038

Ponnusamy, G., \& Ho, J. S. (2015). Customers as volunteers? E-customer citizenship behavior and its antecedents. Information Management and Business Review, 7(3), 50-58.

Riketta, M. (2002). Organizational commitment and job performance: A meta-analysis. Journal of Organizational Behavior, 23(3), 257-266. https://doi.org/10.1002/job.141

Rojas-Mendez, J. I., Vasquez-Parrage, A. Z., Kara, A., \& Cerda-Urrutia, A. (2009). Determinants of student loyalty in higher education: A tested relationship approach in Latin America. Lait American Business Review, 10(1), 21-39. https://doi.org/10.1080/10978520903022089

Roostika, R. (2011). The effect of perceived service quality and trust on loyalty: Customer's perspectives on mobile Internet adoption. International Journal of Innovation, Management, and Technology, 2(4), 286-291.

Schirmer, N., Ringle, C. M., Gudergan, S. P., \& Feistel, M. S. (2016). The link between customer satisfaction and loyalty: The moderating role of customer characteristics. Journal of Strategic Marketing, 1-20. https://doi.org/10.1080/0965254X.2016.1240214

Seppanen, R., \& Blomqvist, K. S. (2007). Measuring inter-organizational-trust- A critical review of the empirical research in 1993-2003. Industrial Marketing Management, 36(2), 249-265. https://doi.org/10.1016/j.indmarman.2005.09.003

Soch, H., \& Aggarwal, N. (2013). Influence of commitment on customer discretionary behavior: A survey in retail sector. Universal Journal of Management, 1(2), 103-110.

Tan, V., Quoquab, F., Ahmad, F. S., \& Mohammad, J. (2017). Mediating effects od students' social bonds between self-esteem and customer citizenship behavior in the context of international university branch campuses. Asia Pacific Journal of Marketing and Logistics, 29(2), 305-329. https://doi.org/10.1108/APJML-05-2016-0087

Tomas, S. (2011). What drives student loyalty in universities: An empirical model from India. International Business Research, 4(2), 183-192. https://doi.org/10.5539/ibr.v4n2p183

Tsai, C. Y. D., Wu, S. H., \& Huang, C. T. (2017). From mandatory to voluntary: Consumer cooperation and citizenship behavior. The Services Industrial Journal, 37(7-8), 521-543. https://doi.org/10.1080/02642069.2017.1337099

Weibo, Z., Kaur, S., \& Jun, W. (2010). New development of organizational commitment: A critical review (1960-2009). African Journal of Business, 4(1), 12-20.

Wingwon, B., \& Piriyakul, M. (2010). Determinants of perceived performance, perceived customer citizenship behavior of modern trade in north region Thailand. International Conference, Chiangrai Rajabhat University, Thailand; Gadjah Mada University, Indonesia.

Wirtz, J., \& Mattila, A. S. (2003). The effects of consumer expertise on evoked set size and service loyalty. Journal of Service Marketing, 17(7), 649-665. https://doi.org/10.1108/08876040310501223

Yang, S., \& Qinhai, M. (2011). Review of customer citizenship behaviors scales in service perspective. Springer-Verlag Heidelberg. https://doi.org/10.1007/978-3-642-23993-9_35

Yi, Y., Gong, T., \& Lee, H. (2013). The impact of other customers on customer citizenship behavior. Psychology and Marketing, 30(4), 341-356. https://doi.org/10.1002/mar.20610

Yu-hong, Z., Da-hai, D., \& Sheng-nan, L. (2013). Antecedents and the outcome of customer citizenship behavior in consumption virtual communities: A theoretical model. International Conference on Education Technology and Management Science (pp. 614-617). Amsterdam: Atlantis Press. 


\section{Copyrights}

Copyright for this article is retained by the author, with first publication rights granted to the journal.

This is an open-access article distributed under the terms and conditions of the Creative Commons Attribution license (http://creativecommons.org/licenses/by/4.0/). 